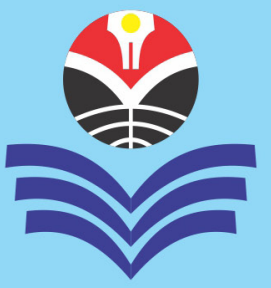

\title{
Local Intruction Theory dalam Pendidikan Matematika Realistik untuk Menumbuhkan Kemampuan Berpikir Logis
}

\begin{abstract}
ABSTRAKSI: Tujuan penelitian ini untuk mengetahui kesulitan belajar Matematika dan perbedaan peningkatan kemampuan berpikir logis siswa, yang diberi perlakuan pembelajaran LIT (Local Instruction Theory) dengan pendekatan PMR (Pendidikan Matematika Realistik) dengan siswa yang hanya diberi pendekatan PMR saja. Metode penelitian berupa "design research", dengan subjek penelitian berjumlah 184 siswa SMP (Sekolah Menengah Pertama), yang berasal dari peringkat sekolah yang berbeda. Hasil penelitian menunjukan bahwa kesulitan belajar yang dialami siswa SMP adalah karena sulit dalam memahami variabel, koefisien, dan konstanta; sulit membaca maksud soal, sulit menyusun strategi dalam menyelesaikan soal; sulit dalam proses perhitungan; dan masih salah dalam penulisan persamaan. Peningkatan kemampuan berpikir logis siswa yang pembelajarannya menggunakan LIT dalam PMR ternyata lebih tinggi daripada siswa yang pembelajarannya menggunakan PMR saja. Perlu kajian lanjutan untuk melihat pengaruh penggunaan LIT dalam PMR terhadap kemampuan Matematis lainnya dan pada berbagai level sekolah.
\end{abstract}

KATA KUNCI: Local Instruction Theory; Kesulitan Belajar; Pendidikan Matematika Realistik; Siswa SMP; Berpikir Logis.

ABSTRACT: "The Local Instruction Theory in Realistic Mathematics Education for Improving the Ability of Logical Thinking". The objective of this study was to determine the Mathematical learning difficulties and differences increase students' ability to think logically whose treated by learning approach LIT (Local Instruction Theory) with RME (Realistic Mathematics Education) and students treated by PMR learning approach only. The research method in the form of design research, with research subjects totaling 184 of JHS (Junior High School) students, derived from different school rankings. The research findings show that the difficulties of learning experienced by JHS students were caused by difficult to understand the variables, coefficients, and constants; difficult to read, to interpret the intent problems, to strategize in solving problems; difficult in the process of calculation; and still wrong in writing the equation. The increasing of logical thinking ability of students in learning to use LIT with RME is higher than students whose learning by using RME only. A further study is required to see the effect of using LIT with RME towards other Mathematical skills and at various school levels. KEY WORD: Local Instruction Theory; Difficulty Learning; Realistic Mathematics Education; Junior High School Students; Logical Thinking.

About the Authors: Tatang Supriatna adalah Mahasiswa SPs UPI (Sekolah Pasca Sarjana, Universitas Pendidikan Indonesia), Jalan Dr. Setiabudhi No.229 Bandung 40154, Jawa Barat, Indonesia. Prof. Dr. Darhim dan Prof. Dr. Turmudi adalah Dosen SPs UPI di Bandung. Untuk kepentingan akademik, penulis bisa dihubungi dengan alamat emel: aenwae@yahoo.co.id, darhim55@yahoo.com,dan turmudi@upi.edu

How to cite this article? Supriatna, Tatang, Darhim \& Turmudi. (2017). "Local Intruction Theory dalam Pendidikan Matematika Realistik untuk Menumbuhkan Kemampuan Berpikir Logis" in MIMBAR PENDIDIKAN: Jurnal Indonesia untuk Kajian Pendidikan, Vol.2(2), September, pp.173-184. Bandung, Indonesia: UPI [Indonesia University of Education] Press, ISSN 2527-3868 (print) and 2503-457X (online).

Chronicle of the article: Accepted (April 26, 2017); Revised (June 30, 2017); and Published (September 30, 2017). 


\section{PENDAHULUAN}

Salah satu fenomena pembelajaran yang sering terjadi adalah mengejar target kurikulum, yang cenderung mengarah pada pola berpikir imitatif dengan mengabaikan kebermaknaan, sehingga proses pembelajaran bersifat kurang kontekstual dan tidak menyentuh terhadap jalan berpikir si pembelajar (Suryadi, 2010; dan Handayani, 2013). Melalui cara berpikir imitatif, siswa dimungkinkan dapat dengan mudah menyelesaikan soal yang serupa dengan contoh soal yang diberikan, namun siswa akan kesulitan saat diberikan soal yang berbeda (Oers, 2012). Hambatanhambatan seperti itu, menurut D.H. Clement (2009) dan D. Suryadi (2010), tergolong "hambatan epistemologis".

Menurut D.H. Clement (2009) dan D. Suryadi (2010), hambatan epistemologis merupakan hambatan yang muncul akibat dari pengetahuan seseorang yang hanya terbatas pada konteks tertentu, sehingga ketika dihadapkan pada konsep yang sama, namun konteksnya yang berbeda, pengetahuan yang dimiliki sebelumnya seakan tidak sesuai dan tidak dapat digunakan lagi, yang dipastikan akan mengalami kesulitan dalam menyelesaikan permasalahan (Clement, 2009; dan Suryadi, 2010).

Hambatan epistemologis terlihat dari ketergantungan siswa pada pengalaman penyelesaian masalah sebelumnya. Jika siswa mengalami hambatan dalam proses belajar (learning obstacle), maka hambatan tersebut dapat menyebabkan siswa mengalami kegagalan atau kurang berhasil dalam mencapai tujuan belajar (Setiawati, 2011; dan Hidayat, Umbara \& Puadi, 2016). Sejumlah penelitian menunjukan kuatnya faktor-faktor di atas sebagai penyebab utama munculnya kesulitan siswa dalam pembelajaran (cf Wadifah, 2010; Supriatna, 2011; Eksan et al. 2014; dan Prahmana, 2016).

Kemampuan berpikir logis masih mendapat berbagai kendala yang dialami siswa dalam memahami materi persamaan dan pertidaksamaan linier satu variabel. Hal ini sesuai dengan karakteristik berpikir logis, sebagaimana dikemukakan oleh M. Aminah (2011) dan W. Hidayat \& U. Sumarmo (2013) tentang bagaimana berpikir menurut pola tertentu atau aturan inferensi logis atau prinsip-prinsip logika untuk memperoleh kesimpulan dan berpikir, yang meliputi: induksi, deduksi, analisis, dan sintesis (Aminah, 2011; dan Hidayat \& Sumarmo, 2013).

Bukti lain masih lemahnya kemampuan siswa dalam berpikir logis adalah berpikir Aljabar. Hal ini terlihat pada data TIMSS (Trends in International Mathematics and Science Study) tahun 2011 terhadap siswa SMP (Sekolah Menengah Pertama) di Indonesia, yang menunjukan bahwa pembelajaran di Indonesia secara umum kurang kontekstual dan kurang menyentuh terhadap jalan berpikir si pembelajar (dalam Rosnawati, 2013; dan Happy \& Widjajanti, 2014). Penalaran Aljabar penting untuk mendorong siswa memahami Matematika di luar hasil perhitungan spesifik dan penggunaan rumus secara prosedural (Victoria et al., 2007; dan Nuraini, Sujadi \& Subanti, 2016).

Menurut K. Hutagaol (2013) bahwa untuk mengantisipasi, mengurangi, atau bahkan menghilangkan hambatan-hambatan yang muncul selama proses pembelajaran, seyogyanya merupakan tugas dan fungsi guru, diantaranya, dengan cara melakukan perancangan pembelajaran yang lebih bersifat kontekstual dan menjembatani cara-cara berpikir si pembelajar, sehingga kompetensi yang sesungguhnya bisa dicapai (Hutagaol, 2013). Dalam proses perkembangannya, pembelajar sesungguhnya memiliki suatu pola tingkatan alamiah, sehingga mereka mengikuti cara belajar dengan kemampuan-kemampuan dan ide-ide Matematika dengan cara mereka sendiri (Susanti, Parta \& Chandra, 2013; dan Fuadi \& Munzir, 2016).

Ketika guru memahami pola tingkatan 
alamiah para pembelajar, dan kemudian menuangkannya melalui rancangan pembelajaran dengan aktivitas-aktivitas yang tersusun di dalamnya, maka mereka sesungguhnya telah membangun suatu lingkungan belajar Matematika yang tepat dan efektif, guna mengembangkan cara berpikir para siswa pembelajarnya (Mulbar, 2015; dan Santi, Sugiarti \& Indah, 2015). Dalam rancangan pembelajaran tersebut, tentu tidak semua hambatan belajar siswa dapat dikurangi ataupun diatasi, karena setiap siswa memiliki hambatan belajar yang berbeda-beda.

Seorang guru harus bisa menggolongkan berbagai macam hambatan belajar tersebut kedalam beberapa golongan, misalnya: kelompok siswa yang masih salah dalam memahami konsep, kelompok siswa yang kurang memahami konsep, dan kelompok siswa yang sama sekali belum memahami konsep yang diajarkan (Ismail, 2016). Tiap kelompok siswa yang memiliki hambatan belajar tersebut nantinya akan ditentukan alternatif didaktisnya. Pola tingkatan alamiah tersebut merupakan dasar dalam membuat learning trajectories, atau lintasan belajar, seperti penelitian yang dilakukan oleh D.H. Clement (2009); H. Empson (2011); Darhim (2012); R.R. Pratamasari \& C.E.T.D. Subanji (2013); Eksan et al. (2014); dan K.I.S. Dewi \& Kusrini (2014).

Berdasarkan wawancara penulis yang dilakukan terhadap beberapa guru Matematika SMP (Sekolah Menengah Pertama) bahwa setiap guru mendambakan para siswanya belajar dengan baik. Namun, dalam kenyataannya, tidaklah demikian. Guru seringkali menemukan beberapa siswa yang mengalami keterbatasan konteks, terkait konsep baru yang diajarkan dan pengetahuan prasyarat yang tidak dimiliki oleh siswa (wawancara dengan Responden A, 2/10/2016; wawancara dengan Responden B, 9/10/2016; dan wawancara dengan Responden C, 16/10/2016).

Hambatan dalam pembelajaran tersebut senada dengan penelitian yang dilakukan oleh S. Predigger (2008) dan T. Supriatna (2011), yakni mengenai jenis-jenis kesalahan siswa dalam belajar Matematika, diantaranya adalah kesalahan dalam melakukan representasi dan interpretasi terhadap soal yang disajikan dalam bentuk soal cerita, yang menyangkut kehidupan sehari-hari (Predigger, 2008; dan Supriatna, 2011). Apabila pembelajaran Matematika diberikan secara terintegrasi dalam kehidupan sehari-hari, siswa akan belajar lebih baik karena lingkungan belajarnya akan berjalan secara alamiah. Siswa akan mengalami apa yang dipelajarinya, bukan mengetahui "Matematika jadi" yang ditransfer oleh guru.

Tugas guru adalah mengkaitkan materi dengan kehidupan yang dialami oleh siswa dalam kehidupan sehari-hari. Hal ini sejalan dengan pendapat A. Lie (2008), yang mengatakan bahwa guru harus melaksanakan pembelajaran berdasarkan pokok-pokok pikiran, sebagai berikut: (1) pengetahuan ditemukan, dibentuk, dan dikembangkan oleh siswa; (2) siswa membangun pengetahuan secara aktif; (3) guru perlu mengembangkan kompetensi siswa, yang berarti bahwa pendidikan harus menekankan pada proses daripada hasil; serta (4) pendidikan adalah interaksi pribadi antara siswa, dan interaksi juga antara guru dan siswa, untuk membangun pengertian dan pengetahuan secara bersama-sama (Lie, 2008:4).

PMR (Pendidikan Matematika Realistik) dipandang dapat mengakomodir keinginankeinginan tersebut, karena pembelajaran dengan menggunakan Matematika realistik mempunyai karakteristik dimana pembelajaran Matematika adalah aktivitas manusia; dan Matematika harus dihubungkan secara nyata terhadap konteks kehidupan sehari-hari siswa sebagai sumber pengembangan dan sebagai area aplikasi melalui proses Matematisasi, baik secara horizontal maupun vertikal (cf Zulkardi \& Putri, 2010; dan Zulkardi et al., 2013). 
Beberapa prinsip utama dalam RME (Realistic Mathematic Education) atau PMR, yakni: penemuan terbimbing dan ber-Matematika secara progresif atau guided reinvention and progressive Mathemativation; fenomena mendidik atau didactical phenomenology; dan model pengembangan mandiri atau self developed model (Zulkardi \& Putri, 2010). Terdapat lima karakteristik dalam pendekatan RME, yakni: (1) use of contexts for phenomenologist explorations; (2) use of models for Mathematical concept contruction; (3) use of student' creations and contribution; (4) use of students activity and interactivity on the learning process; dan (5) intertwining Mathematics concept, aspects, and units (dalam Zulkardi \& Putri, 2010; dan Zulkardi et al., 2013).

Selain itu, seandainya sebelum pembelajaran dilangsungkan, guru sudah mengetahui kesulitan-kesulitan dan hambatan dalam LIT (Local Instruction Theory), yang kemungkinan akan dialami peserta didik, maka guru perlu berpikir lebih awal untuk mempersiapkan bahan, metode, dan strategi penyajian yang sesuai, sehingga peserta didik senantiasa berada pada lintasan alternatif, atau HLT (Hypothetical Learning Trajectory), yang sesuai dengan harapan sehingga bisa mencapai tujuan pembelajaran yang diinginkan (Baroody et al., 2010; dan Confrey \& Maloney, 2010). Guru juga perlu membuat prediksi tentang bagaimana kemungkinan siswa belajar sesuai dengan kapasitasnya, dimana prediksi guru dalam hal ini berkaitan dengan bagaimana mengembangkan kemampuan berpikir dan pemahaman siswa melalui aktivitas belajar yang dirancang oleh guru (Yanti, Hartono \& Somikin, 2016).

Suatu HLT, atau LBH (Lintasan Belajar Hipotesis), senantiasa disiapkan oleh guru dan didasarkan pada pemikiran kemungkinan kesulitan atau hambatan yang dialami oleh peserta didik, sehingga hasil belajar terbaik dapat dicapai (Suryadi, 2010; dan Supriatna 2011). Hal ini dapat terlihat dalam pemikiran dan perencanaan yang terjadi dalam pengajaran, termasuk respon spontan yang dibuat dalam menanggapi pemikiran peserta didik. Pengajuan LT (Learning Trajectory) dapat berupa hipotesis, karena pengalaman guru membuat keputusan dan mengadaptasi aspek-aspek dari aktivitas yang direncanakan dalam respon adalah untuk menunjukan pemikiran dan belajar yang dialami peserta didik, perbedaan aspek dan tingkat pemahaman, sehingga akan menjadi jelas terlihat bagi guru berkenaan (Barrett et al., 2011).

Selain itu, istilah "hipotesis" digunakan agar guru menjadi lebih fleksibel dalam mengubah arah pembelajaran dan mengadaptasi aspek-aspek aktivitas yang telah direncanakan dalam menanggapi respon peserta sepanjang pembelajaran (Barrett et al., 2011; dan Khuriyati, Hartono \& Somakin, 2015). LT yang dirancang itu masih berupa hipotesis atau dugaan, maka kemudian disebut dengan HLT atau Hypothetical Learning Trajectory (Marlina, 2016; dan Yanti, Hartono \& Somakin, 2016).

Pengembangan HLT diformulasikan dalam tiga komponen, yaitu: (1) tujuan pembelajaran; (2) instrumen pembelajaran yang akan digunakan; dan (3) hypothetical learning process untuk mengantisipasi bagaimana proses berpikir kritis dan kreatif Matematis peserta didik yang akan dikembangkan (Suryadi, 2010). Dalam mengembangkan suatu disain rancangan pembelajaran perlu memformulasikan HLT, serta memperhatikan pula segi didaktis dan pedagogis yang terdapat di dalamnya (Zulkardi et al., 2013).

Secara umum, tujuan penelitian ini adalah untuk mengetahui kesulitan belajar siswa SMP (Sekolah Menengah Pertama), dan perbedaan peningkatan kemampuan berpikir logis pada siswa SMP yang diberi perlakuan pembelajaran hanya dengan pendekatan PMR (Pendidikan Matematika Realistik) dan siswa yang diberi perlakuan 


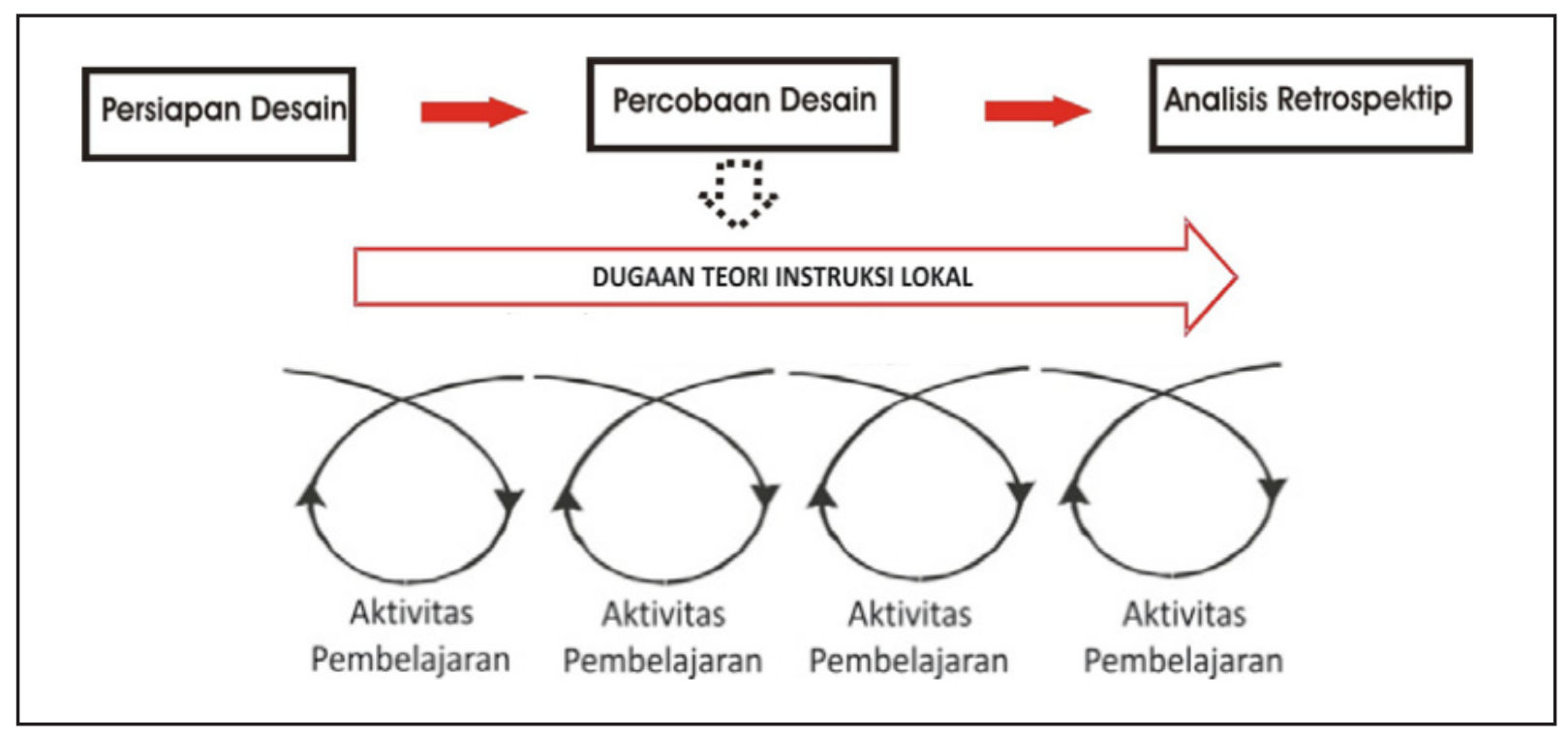

Diagram 1:

Hubungan Reflektif antara Teori dan Percobaan

pembelajaran dengan pendekatan PMR ditambah LIT (Local Instruction Theory).

\section{METODE}

Metode yang digunakan dalam penelitian ini adalah design research (Brouseau, 1997; Gall, Borg \& Gall, 2003; Gravemeijer \& Cobb, 2006; Lidinillah, 2011; dan Suryadi, 2011), dengan fase desain penelitian diringkas ke dalam diagram 1 .

Proses siklik berdasarkan diagram 1, yaitu dari eksperimen pemikiran kemudian ke eksperimen pembelajaran dalam bentuk gambar; dan ilustrasi ide percobaan tersebut berasal dari K. Gravemeijer \& P. Cobb (2006).

Subjek penelitian adalah 129 siswa kelas VII SMPN (Sekolah Menengah Pertama Negeri) 1 dan SMPN 8 Sumedang, Jawa Barat, Indonesia. Hasil dari tahap pilot experiment telah dipublikasikan pada Seminar Nasional di UNSIL (Universitas Siliwangi) di Tasikmalaya, Jawa Barat, pada tahun 2016. Tahap teaching experiment melibatkan sebanyak 129 siswa.

Bagian dari design reseach adalah pengembangan teori antara proses pembelajaran dan mendukung pembelajaran (Brouseau, 1997; Gravemeijer \& Cobb, 2006; dan Suryadi, 2011). Tahapan penelitian diuraikan, sebagai berikut: (1) Preliminary Design; (2) Teaching Experiment; dan (3) Retrosperctive Analysis. Di bawah ini penjelasan dari masing-masing tahapan.

Pertama, Preliminary Design. Dalam tahap preliminary design ini, peneliti merancang ide awal yang dimulai dari mempelajari berbagai buku sumber terkait materi persamaan dan pertidaksamaan linier satu variabel. Langkah selanjutnya, peneliti mendesain HLT (Hypothetical Learning Trajectory) yang memuat tujuan pembelajaran, aktivitas pembelajaran, dan dugaan cara berpikir siswa dari tahap informal ke tahap formal ( $c f$ Widjaja, 2008; Khuriyati, Hartono \& Somakin, 2015; dan Utari, Putri \& Hartono, 2015).

Kedua, Teaching Experiment. Pada tahap ini, HLT yang telah disusun diujicobakan secara bertahap, dimulai dari pilot experiment, yang dalam tahap ini peneliti bertindak sebagai guru model. Tahap teaching experiment dilakukan pada kelompok besar, yang dalam tahap ini 
peneliti bertindak sebagai observer, dan pengajar adalah guru mata pelajaran di sekolah tersebut. Revisi HLT yang menjadi LIT (Local Instruction Theory) dilaksanakan pada tahap ini, sehingga pola pikir dan strategi siswa terlihat pada materi persamaan dan pertidaksamaan linier satu variabel (Widjaja, 2008; dan Larsen, 2013).

Ketiga, Retrosperctive Analysis. Pada tahap

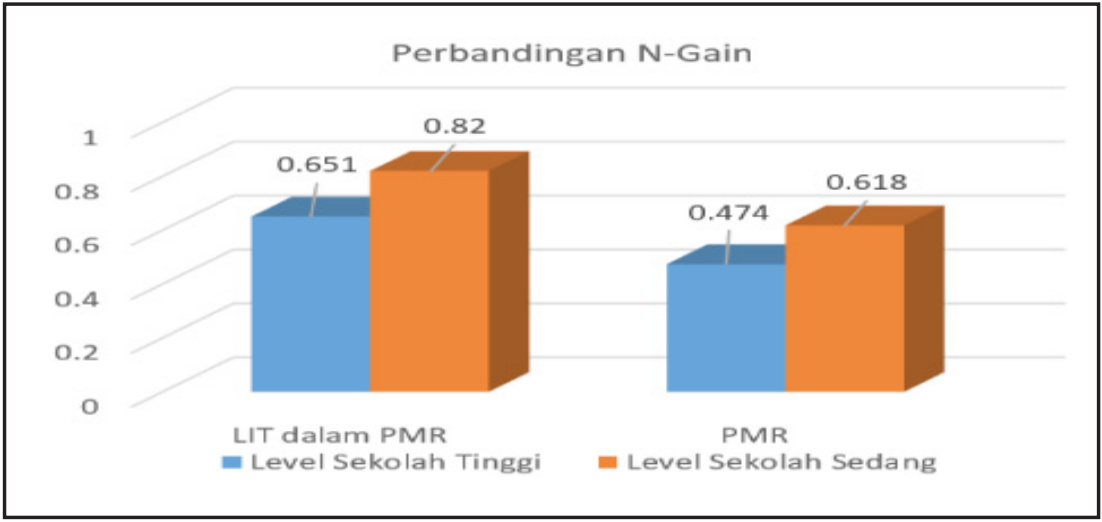

Diagram 2:

Perbandingan Persentase $\mathrm{N}$-Gain Kemampuan Berpikir Logis Berdasarkan Peringkat Sekolah dan Kelompok Perlakuan ini, peneliti melakukan refleksi terhadap pembelajaran pada tahap teaching experiment. Pada tahap ini pula HLT yang telah didesain dibandingkan dengan proses pembelajaran siswa yang sebenarnya untuk menjawab rumusan masalah penelitian. Secara umum, tujuan restrospective analysis adalah untuk mengembangkan LIT (Zulkardi et al., 2013; Zabeta, Hartono \& Putri, 2015; dan Prahmana, 2016).

Sesuai dengan tujuan penelitian LIT dalam PMR (Pendidikan Matematika Realistik), yakni untuk menumbuhkembangkan berpikir logis dan berpikir Aljabar, maka dirancang perangkat pembelajaran dan bahan ajar yang didesain berdasarkan karakteristik pendekatan LIT dalam PMR (Widjaja, 2008; Larsen, 2013; Zulkardi et al., 2013; dan Prahmana, 2016). Perangkat pembelajarn dalam penelitian ini adalah RPP (Rencana Pelaksanaan Pembelajaran), dan bahan ajar yang dikembangkan adalah buku siswa yang menggunakan pendekatan PMR, yang dilengkapi dengan LIT, serta lembar aktivitas kerja siswa yang menggunakan pendekatan PMR dan dilengkapi dengan LIT juga.

Bahan ajar yang dikembangkan dimulai dengan menganalisis buku sumber yang sudah ada. Setelah tahap analisis, maka dibuatkan bahan ajar dengan menggunakan pendekatan PMR, serta memperhatikan beberapa kemungkinan lintasan belajar siswa, karakteristik kesulitan siswa, dan hambatan yang dialami siswa sehingga bahan ajar yang dikembangkan lebih mudah dipelajari dan dipahami oleh siswa.

Intrumen yang digunakan adalah tes dan lembar observasi. Lembar observasi tidak dianalisis secara statistik, tetapi hanya digunakan untuk bahan masukan bagi peneliti dalam melakukan pembahasan secara deskriptif. Dalam mengevaluasi berpikir Aljabar siswa dilakukan penskoran terhadap jawaban siswa untuk setiap butir soal. Kriteria penskoran berpedoman pada acuan yang dikemukakan oleh J. Cai, M.S. Jakabcsin \& S. Lane (1996), dan dikutip juga oleh Nanang (2009), melalui Holistic Scoring Rubrics (Cai, Jakabcsin \& Lane, 1996; dan Nanang, 2009).

\section{HASIL DAN PEMBAHASAN}

Data perolehan rata-rata $N$-Gain untuk kemampuan berpikir logis berdasarkan peringkat, baik siswa dari peringkat sekolah tinggi maupun siswa dari peringkat sekolah sedang, serta perlakuan pembelajaran LIT (Local Instruction Theory) dengan PMR (Pendidikan Matematika Realistik) dan pendekatan PMR saja, dapat dilihat dalam diagram 2 . 
Dari diagram 2 terlihat bahwa $\mathrm{N}$-Gain kemampuan berpikir logis pada siswa yang mendapat perlakuan pembelajaran LIT (Local Instruction Theory) dengan PMR (Pendidikan Matematika Realistik) dari dua peringkat sekolah cenderung selalu lebih tinggi dibandingkan dengan siswa yang mendapat perlakuan pembelajaran PMR saja. Selain itu, $N$-Gain pada siswa dari peringkat sekolah sedang cenderung selalu lebih tinggi dibandingkan dengan siswa yang berasal dari peringkat sekolah tinggi.

Untuk melihat lebih jelasnya, terkait perbandingan perolehan $\mathrm{N}$-Gain kemampuan berpikir logis, baik siswa dari peringkat sekolah tinggi maupun siswa dari peringkat sekolah sedang, dan perlakuan pembelajaran LIT dengan PMR dan pendekatan PMR saja dapat dilihat pada diagram 3 .

Dari diagram 3 terlihat bahwa berdasarkan peringkat sekolah, kelompok perlakuan dan PAM (Pengetahuan Awal Matematis), ternyata pencapaian $N$-Gain yang paling besar dialami oleh kelompok atas yang mendapat perlakuan LIT (Local Instruction Theory) dengan PMR (Pendidikan Matematika Realistik) dari peringkat sekolah sedang; sedangkan pencapaian $N$-Gain yang paling kecil dialami oleh kelompok tengah yang mendapat perlakuan PMR saja dari peringkat sekolah tinggi.

Untuk melihat secara visual, terkait interaksi antara perlakuan pembelajaran dan peringkat sekolah terhadap peningkatan kemampuan berpikir logis siswa, dapat dilihat pada diagram 4.

Diagram 4 menunjukan bahwa pada setiap peringkat sekolah, siswa yang mendapat perlakuan pembelajaran LIT (Local Instruction Theory) dengan PMR

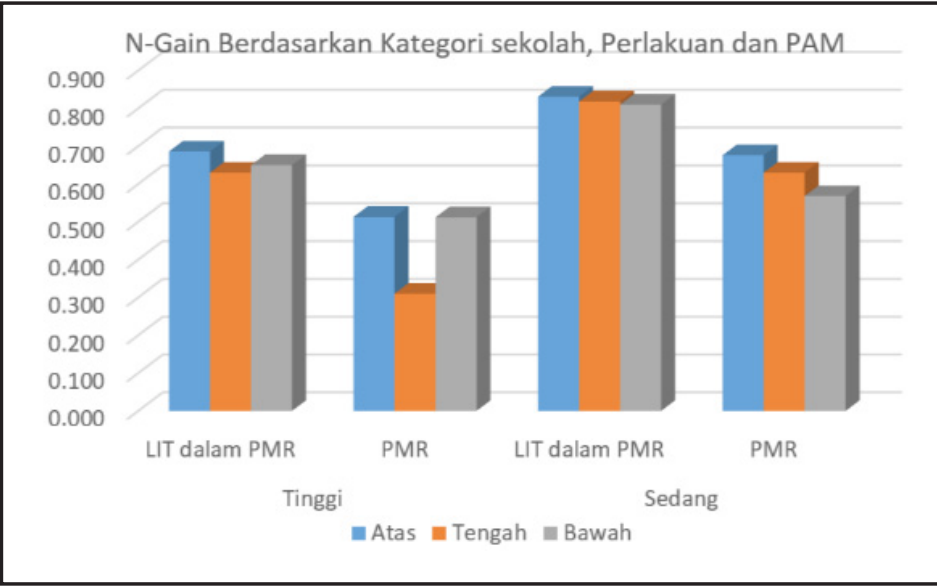

Diagram 3:

Perbandingan Persentase $\mathrm{N}$-Gain Kemampuan Berpikir Logis Berdasarkan Peringkat Sekolah, Kelompok Perlakuan, dan PAM

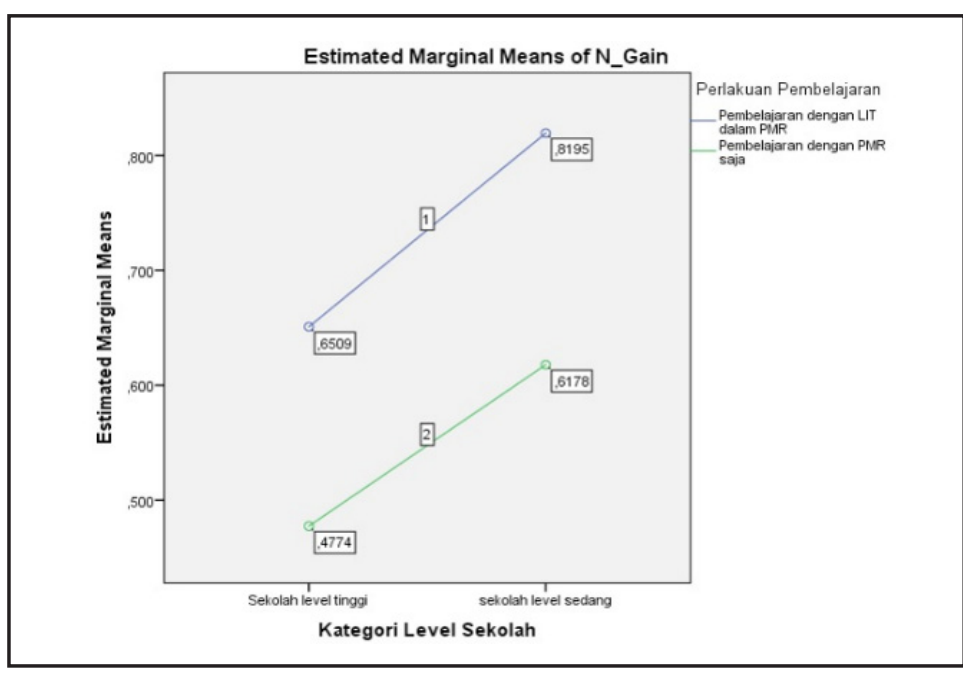

Diagram 4:

Interaksi antara Perlakuan Pembelajaran dan Peringkat Sekolah terhadap Peningkatan Kemampuan Berpikir Logis

(Pendidikan Matematika Realistik), peningkatan kemampuan berpikir logisnya lebih tinggi daripada siswa yang hanya mendapat perlakuan pembelajaran PMR saja. Pada peringkat sekolah sedang, selisih peningkatan kemampuan berpikir logis antara siswa yang mendapat perlakuan pembelajaran LIT dengan PMR dengan siswa yang hanya mendapat perlakuan pembelajaran PMR saja sebesar 0.202. Sedangkan pada peringkat sekolah tinggi, selisih peningkatan kemampuan berpikir 
logis antara siswa yang mendapat perlakuan pembelajaran LIT dengan PMR dengan siswa yang hanya mendapat perlakuan pembelajaran PMR saja sebesar 0.74 .

Hal tersebut menunjukan bahwa peningkatan kemampuan berpikir logis peringkat sekolah sedang lebih besar daripada peningkatan kemampuan berpikir logis peringkat sekolah tinggi, atau dapat disintesis bahwa perlakuan pembelajaran LIT dengan PMR cenderung lebih baik digunakan pada siswa yang berasal dari peringkat sekolah sedang daripada siswa peringkat sekolah tinggi.

Untuk melihat lebih jelasnya secara visual, terkait interaksi antara perlakuan pembelajaran dan PAM (Pengetahuan Awal Matematis) terhadap peningkatan kemampuan berpikir logis siswa, dapat dilihat pada diagram 5 .

Diagram 5 menunjukan bahwa pada setiap kelompok PAM (Pengetahuan Awal Matematis), siswa yang mendapat perlakuan pembelajaran LIT (Local Instruction Theory) dengan PMR (Pendidikan Matematika Realistik) mengalami peningkatan kemampuan berpikir logis yang lebih tinggi daripada siswa yang hanya mendapat perlakuan pembelajaran PMR saja. Pada PAM kelompok atas, selisih peningkatan kemampuan berpikir logis antara siswa yang mendapat perlakuan pembelajaran LIT dengan PMR dengan siswa yang hanya mendapat perlakuan pembelajaran PMR saja sebesar 0.2168. Pada PAM kelompok tengah, selisih peningkatan kemampuan berpikir logis antara siswa yang mendapat perlakuan pembelajaran LIT dengan PMR dengan siswa yang hanya mendapat perlakuan pembelajaran PMR saja sebesar 0.1644. Sedangkan pada PAM kelompok bawah, selisih peningkatan kemampuan berpikir logis antara siswa yang mendapat perlakuan pembelajaran LIT dengan PMR dibandingkan dengan siswa yang hanya mendapat perlakuan pembelajaran PMR saja sebesar 0.2180 .

Hal tersebut menunjukan bahwa peningkatan kemampuan berpikir logis siswa dari kelompok PAM bawah yang mendapat perlakuan pembelajaran LIT dengan PMR mengalami peningkatan kemampuan berpikir logis paling tinggi daripada siswa yang mendapat perlakuan PMR saja, dan juga kelompok PAM lainnya. Disusul oleh siswa dari kelompok PAM atas yang mendapat perlakuan pembelajaran LIT dengan PMR, baru kemudian pencapaian siswa dari kelompok PAM tengah.

Dengan demikian dapat disintesis bahwa perlakuan pembelajaran LIT dengan PMR cenderung lebih baik digunakan pada siswa yang berasal dari kelompok bawah daripada siswa yang berasal dari kelompok atas. 


\section{KESIMPULAN}

Penggunaan LIT (Local Instruction Theory) dengan PMR (Pendidikan Matematika Realistik) dapat menumbuhkembangkan kemampuan berpikir logis siswa. Kesulitan belajar yang dialami siswa dalam mempelajari materi persamaan dan pertidaksamaan linier satu variabel, ditinjau dari keseluruhan sampel, terletak pada: sulit dalam memahami variabel, koefisien, dan konstanta; sulit membaca atau mengartikan maksud soal atau sulit menyusun strategi dalam menyelesaikan soal, sulit dalam proses perhitungan; serta masih salah dalam penulisan persamaan. Siswa dari peringkat sekolah yang tinggi hanya sebagian kecil yang masih mengalami kesulitan. Sedangkan pada siswa dari peringkat sekolah sedang, hampir setengahnya mengalami kesulitan.

Pada keseluruhan sampel, peningkatan kemampuan berpikir logis siswa yang pembelajarannya menggunakan LIT dengan PMR ternyata lebih tinggi daripada siswa yang pembelajarannya hanya menggunakan PMR saja. Pada peringkat sekolah tinggi, peningkatan kemampuan berpikir logis siswa yang pembelajarannya menggunakan LIT dengan PMR, lebih tinggi daripada siswa yang pembelajarannya hanya menggunakan PMR saja. Pada peringkat sekolah sedang, peningkatan kemampuan berpikir logis siswa yang pembelajarannya menggunakan LIT dengan PMR, lebih tinggi daripada siswa yang pembelajarannya hanya menggunakan PMR saja. Selain itu, siswa dari peringkat sekolah sedang yang pembelajarannya menggunakan LIT dengan PMR, peningkatan kemampuan berpikir logisnya lebih tinggi daripada siswa peringkat sekolah sedang.

Pada PAM (Pengetahuan Awal Matematis) siswa atas, peningkatan kemampuan berpikir logis siswa yang pembelajarannya menggunakan LIT dengan PMR, lebih tinggi daripada siswa yang pembelajarannya hanya menggunakan PMR saja. Pada PAM siswa tengah dan bawah, peningkatan kemampuan berpikir logis siswa yang pembelajarannya menggunakan LIT dengan PMR, lebih tinggi daripada siswa yang pembelajarannya hanya menggunakan PMR saja. Selain itu, siswa dari peringkat sekolah sedang yang pembelajarannya menggunakan LIT dengan PMR, dengan PAM tinggi, tengah, dan rendah, mengalami peningkatan kemampuan berpikir logis yang lebih tinggi daripada siswa peringkat sekolah tinggi dengan PAM tinggi, tengah, dan rendah. Tidak terdapat interaksi yang signifikan antara perlakuan pembelajaran dan PAM siswa terhadap pencapaian dan peningkatan kemampuan berpikir logisnya.

Berdasarkan kesimpulan dan implikasi penelitian ini, selanjutnya dikemukakan saran-saran bahwa penggunaan LIT dengan PMR pada siswa yang prestasi sekolahnya belum optimal, hendaknya menjadi salah satu alternatif pilihan guru dalam pembelajaran Matematika sehari-hari. Kemampuan berpikir logis merupakan kemampuan yang penting dalam pembelajaran Matematika di sekolah. Oleh karena itu, kemampuan-kemampuan tersebut perlu terus diteliti dan dikembangkan pada semua tingkatan sekolah, sejak dari SD (Sekolah Dasar) hingga SMA (Sekolah Menengah Atas).

Bagi guru, materi dalam Matematika saling berkaitan satu sama lain. Untuk itu, sebelum menyampaikan suatu materi, hendaknya guru memastikan bahwa materi prasyarat telah dikuasai dengan baik oleh siswa, sehingga dapat memudahkan guru menjelaskan materi selanjutnya. Selain itu, hendaknya guru menganalisis hasil pekerjaan siswa untuk mengetahui kesulitan yang dialami siswa agar kesulitan serupa dapat dihindari.

Bagi peneliti selanjutnya, kajian ini dapat dilanjutkan dengan meneliti pengaruh penggunaan LIT dengan PMR terhadap 
kemampuan Matematis lainnya dan pada berbagai level sekolah. Kajian ini juga dapat dilanjutkan dengan meneliti pada masingmasing indikator kemampuan lainnya, agar diperoleh hasil yang lebih spesifik dan akurat tentang indikator mana saja yang dapat ditingkatkan.

\section{Referensi}

Aminah, M. (2011). "Mengembangkan Kemampuan Berpikir Logis Matematis melalui Pembelajaran Metakognitif'. Makalah pada Sekolah Pascasarjana UPI [Universitas Pendidikan Indonesia) di Bandung.

Baroody, A.J. et al. (2010). "Fostering at-Risk Primary-Grade Children's Fluency with Basic Addition Combinations". Paper presented at the Annual Meeting of the Society for Research on Educational Effectiveness in Washington, D.C.

Barrett, B. et al. (2011). Learning Trajectories in Mathematics. USA [United States of America]: CPRE Publishers.

Brouseau, G. (1997). Theory of Didactical Situation in Mathematics. Dordrecht: Kluwer Academic Publishers.

Cai, J., M.S. Jakabcsin \& S. Lane. (1996). “Assessing Students' Mathematical Communication" in School Science and Mathematics, Vol.96(5), May. Available online also at: http://citeseerx.ist.psu. edu/viewdoc/download?doi=10.1.1.911.3460\&rep $=$ rep1\&type $=$ pdf $[$ diakses di Bandung, Indonesia: 21 Februari 2017].

Clement, D.H. (2009). "Learning Trajectories in Early Mathematics: Sequences of Acquisition and Teaching" in Encyclopedia of Language and Literacy Development, pp.1-7.

Confrey, J. \& A. Maloney. (2010). "The Construction, Refinement, and Early Validation of the Equipatitioning Learning Trajectory" in Journal of ICLS, Vol.1, pp.968-975.

Darhim. (2012). "Pengembangan Bahan Ajar Pendidikan Matematika". Tersedia secara online

\footnotetext{
${ }^{1}$ Pernyataan: Kami, dengan ini, menyatakan bahwa artikel ini beserta seluruh isinya adalah benar-benar karya kami melalui hasil penelitian. Kami tidak melakukan penjiplakan atau pengutipan dengan cara-cara yang tidak dibenarkan dalam etika keilmuan yang berlaku dalam dunia akademis. Kami bersedia menanggung hukuman secara akademik, sekiranya pernyataan yang kami buat ini tidak sesuai dengan kenyataan. Demikian surat pernyataan ini dibuat untuk dipergunakan sebagaimana mestinya.
}

di: http://file.upi.edu/Direktori/FPMIPA/JUR. PEND. MATEMATIKA/195503031980021DARHIM/Media Pemb Mat/

PengembanganBahanAjar.pdf [diakses di Bandung, Indonesia: 15 Febrari 2017].

Dewi, K.I.S. \& Kusrini. (2014). “Analisis Kesalahan Siswa Kelas VIII dalam Menyelesaikan Soal pada Materi Faktorisasi Bentuk Aljabar" dalam Jurnal Ilmiah Pendidikan Matematika.

Eksan et al. (2014). "Penerapan Inkuri Terbimbing" dalam Jurnal FKIP UNILA. Lampung: FKIP UNILA [Fakultas Keguruan dan Ilmu Pendidikan, Universitas Negeri Lampung].

Empson, H. (2011). "On the Idea of Learning Trajectories: Promises and Pitfalls" in Journal of the Mathematisc Enthusiats.

Fuadi, K.J. \& R. Munzir. (2016). "Peningkatkan Kemampuan Pemahaman dan Penalaran Matematis melalui Pendekatan Kontekstual" dalam Jurnal Didaktika Matematika, Vol.3, No.1.

Gall, M.D., W.R. Borg \& J.P. Gall. (2003). Educational Research: An Introduction. USA [United States of America]: Pearson Education, Inc.

Gravemeijer, K. \& P. Cobb. (2006). "Design Research: From a Learning Design Perspective" in Educational Design Research, pp.17-55.

Handayani, Dwi Aprilia. (2013). "Penalaran Kreatif Matematis" dalam Jurnal Pengajaran MIPA, Vol.18, No.2.

Happy, N. \& B.D. Widjajanti. (2014). "Keefektifan PBL Ditinjau dari Kemampuan Berpikir Kritis dan Kreatif Matematis, serta Self-Esteem Siswa SMP" dalam Jurnal Riset Pendidikan Matematika, Vol.1, No.1.

Hidayat, D., U. Umbara \& E.V.W. Puadi. (2016). "Pengembangan Disain Didaktis Persaman Linier Satu Variabel pada Pembelajaran Matematika di MTsN Model Cigugur" dalam Jurnal Matematika Ilmiah, Vol.2, No.2.

Hidayat, W. \& U. Sumarmo. (2013). "Kemampuan Komunikasi dan Berpikir Logis Matematika serta Kemandirian Belajar" dalam Jurnal Delta- $f$, Vol.2, No.1.

Hutagaol, K. (2013). "Innovations in Science and Mathematics Education" dalam Jurnal Infinity, Vol.2, No.1.

Ismail. (2016). "Diagnosis Kesulitan Belajar Siswa dalam Pembelajaran Aktif di Sekolah" dalam Jurnal Edukasi, Vol.2, No.1.

Khuriyati, L. Hartono \& H. Somakin. (2015). "Desain Pembelajaran Menggunakan Operasi Pecahan Menggunakan Kertas Berpetak di Kelas IV" dalam Jurnal Paradikma, Vol.8, No.3.

Larsen, S.P. (2013). “A Local Insructional Theory for the Guided Reinvention of the Group and Isomorphism Concept" in The Journal of 
Mathematical Behavior. Tersedia secara online juga di: www.elsevier.com/locate/jmathb [diakses di Bandung, Indonesia: 21 Februari 2017].

Lidinillah, D.A.M. (2011). “Design Research sebagai Penelitian Pendidikan: A Theoretical Framework for Action". Makalah Tidak Diterbitkan. Bandung: UPI [Universitas Pendidikan Indonesia].

Lie, A. (2008). Cooperative Learning: Mempraktikan Cooperative Learning di Ruang-ruang Kelas. Jakarta: Gramedia Widia Sarana Indonesia, Terjemahan.

Marlina, R. (2016). “Desain Pembelajaran Kelipatan Persekutuan Terkecil dengan Menggunakan Pendekatan PMRI" dalam Prosiding Seminar Nasional Pendidikan, Vol.1, No.1.

Mulbar. (2015). "Pengembangan Desain Pembelajaran Matematika dengan Memanfaatkan Sistem Sosial Masyarakat" dalam Jurnal Cakrawala Pendidikan, Vol.34, No.2.

Nanang. (2009). "Studi Perbandingan Kombinasi Pembelajaran Kontekstual dan Metakognitif terhadap Kemampuan Pemahaman dan Pemecahan Masalah Matematika Siswa SMP”. Disertasi Doktor Tidak Diterbitkan. Bandung: SPs UPI [Sekolah Pascasarjana Universitas Pendidikan Indonesia].

Nuaraini, L., Sujadi \& S. Subanti. (2016). "Penalaran Aljabar Siswa Kelas VII SMP Negeri 1 Margoyoso Kabupaten Pati dalam Pemecahan Masalah Matematika" dalam Jurnal Elektronik Pembelajaran Matematika, Vol.4, No.6.

Oers. (2012). "Meaningful Cultural Learning by Imitative Participation: The Case of Abstract Thinking in Primary School" in Journal Human Development, Vol.55, No.22. Tersedia secara online juga di: https://research.vu.nl/ en/publications/meaningful-cultural-learningby-imitative-participation-the-case [diakses di Bandung, Indonesia: 18 Februari 2017].

Prahmana, R.C.I. (2016). "Local Instruction Theory: Penelitian Pendidikan Matematika untuk Menumbuhkembangkan Keterampilan Mahasiswa Calon Guru dalam Melakukan Penelitian dan Menulis Karya Ilmiah". Karya Ilmiah Tidak Diterbitkan.

Pratamasari, R.R. \& C.E.T.D. Subanji. (2013). "Penelusuran Kesalahan Siswa dan Pemberian Scaffolding dalam Menyelesaikan Bentuk Aljabar". Makalah Ilmiah Tidak Diterbitkan.

Predigger, S. (2008). “The Relevance of Didactic Categories for Analysing Obstacles in Conceptual Change: Revisiting the Case of Multiplication of Fractions" in Learning and Instruction: Preliminary Version. Germany: IEEM - Institute for Development and Research in Mathematics
Education, University of Dortmund. Tersedia secara online juga di: www.prediger@math.unidortmund.de [diakses di Bandung, Indonesia: 9 Oktoner 2016].

Rosnawati, R. (2013). "Kemampuan Penalaran Matematika Siswa SMP Indonesia pada TIMSS 2011" dalam Prosiding Seminar Nasional Penelitian, Pendidikan, dan Penerapan MIPA di Fakultas MIPA UNY [Matematika dan Ilmu Pengetahuan Alam, Universitas Negeri Yogyakarta], pada tanggal 18 Mei.

Santi, D., T. Sugiarti \& A. Indah. (2015). "Pengembangan Perangkat Pembelajaran Matematika Realistrik pada Pokok Bahasan Lingkaran di Kelas VIII" dalam Jurnal Kadikma, Vol.6, No.1.

Setiawati, E. (2011). "Hambatan Epistimologis dalam Persamaan Kuadrat pada Siswa Madrasah Aliyah" dalam Proceeding International Seminar and the Fourth National Conference on Mathematics Education.

Supriatna, T. (2011). "Disain Didaktis Luas Daerah Segitiga Sekolah Menengah Pertama untuk Meningkatkan Kemampuan Pemecahan Masalah". Laporan Penelitian Tidak Diterbitkan. Bandung: LPPM UPI [Lembaga Penelitian dan Pengabdian Masyarakat, Universitas Pendidikan Indonesia].

Suryadi, D. (2010). "DDR dalam Pengembangan Pembelajaran Matematika". Makalah disajikan dalam Seminar Nasional Pembelajaran MIPA (Matematika dan Ilmu Pengetahuan Alam) di UM (Universitas Negeri Malang).

Suryadi, D. (2011). "Didactical Design Research (DDR) dalam Pengembangan Pembelajaran Matematika". Makalah pada Join-Conference UPI-UiTM di Bandung, pada tanggal 25 April.

Susanti, E., N.I. Parta \& D.T. Chandra. (2013). "Profil Berpikir Siswa dalam Mengkontruksi Ide-ide Matematis Berdasarkan Taksonomi Solo". Makalah disajikan dalam KNPM (Konferensi Nasional Pendidikan Matematika) V, diselenggarakan oleh Himpunan Matematika Indonesia.

Utari, S.R., I.I.R. Putri \& Y. Hartono. (2015). "Konteks Kebudayaan Palembang untuk Mendukung Kemampuan Bernalar Siswa SMP pada Materi Perbandingan" dalam Jurnal Didaktik Matematika, Vol.2, No.2.

Victoria, J. et al. (2007). "Professional Development Focused on Children's Algebraic Reasoning in Elementary School" in Journal for Research in Mathematics Education, Vol.38, No.3. Tersedia secara online juga di: http://www.jstor.org/ stable/30034868?seq=1\#page scan tab contents [diakses di Bandung, Indonesia: 19 Februari 2017]. 
Wadifah. (2010). "Hambatan Epistimologis dalam Memahami Konsep Luas Daerah Segitiga". Karya Ilmiah Tidak Diterbitkan. Bandung: UPI [Universitas Pendidikan Indonesia].

Wawancara dengan Responden A, seorang Guru Matematika SMP (Sekolah Menengah Pertama) di Bandung, Jawa Barat, Indonesia, pada tanggal 2 Oktober 2016.

Wawancara dengan Responden B, seorang Guru Matematika SMP (Sekolah Menengah Pertama) di Purwakarta, Jawa Barat, Indonesia, pada tanggal 9 Oktober 2016.

Wawancara dengan Responden C, seorang Guru Matematika SMP (Sekolah Menengah Pertama) di Sumedang, Jawa Barat, Indonesia, pada tanggal 16 Oktober 2016.

Widjaja, W. (2008). "Local Intruction Theory on Decimals: The Case of Indonesian Pre-Service Teachers". Unpublished Ph.D. Dissertation. Merbourne: Graduate School of Education, University of Melbourne, Australia.
Yanti, W., Y. Hartono \& Somakin. (2016). “Desain Pembelajaran Peluang dengan Pendekatan PMRI: Menggunakan Kupon Undian untuk Siswa Kelas VII" dalam Jurnal Elemen, Vol.2, No.1.

Zabeta, Hartono \& Putri. (2015). "Desain Pembelajaran Materi Pecahan Menggunakan Pendekatan PMRI" dalam BETA: Jurnal Tadris Matematika.

Zulkardi \& R.I. Putri. (2010). "Pengembangan Blog Support untuk Membantu Siswa dan Guru Matematika dalam Belajar Pendidikan Matematika Realistik Indonesia" dalam JIPP: Jurnal Inovasi Perekayasa Pendidikan, Vol.2(1), hlm.1-24.

Zulkardi et al. (2013). "Developing a Local Instruction Theory for Learning: The Concept of Angle through Visual Field Activities and Spatial Representations" in International Education Studies, Vol.6, No.2, p-ISSN 1913-9020 and e-ISSN 1913-9039, published by Canadian Center of Science and Education. 